\title{
Sex, Blasphemy, and the Block: The Trial and Execution of Ludwig Hätzer
}

GEOFFREY DIPPLE

Augustana Faculty, University of Alberta

In early 1529, the Protestant authorities of Constance executed Ludwig Hätzer for disobedience and moral depravity. Although the court documents avoided any reference to his religious teachings, contemporaries speculated about the role that perceptions-that he was an Anabaptist who espoused heretical opinions-played in his conviction. This article uses Hätzer's trial and execution as an opportunity to reflect on two topics of interest in studies of the early Reformation: the reluctance of reformers to level charges of heresy against each other, and their re-evaluation of human sexuality resulting from the rejection of clerical celibacy.

Au début de 1529, les autorités protestantes de Constance ont exécuté Ludwig Hätzer pour désobéissance et dépravation morale. Bien que les documents juridiques évitent toute référence à ses enseignements religieux, ses contemporains ont multiplié les conjectures au sujet du rôle qu'a joué dans sa condamnation la conviction qu'il était un anabaptiste ayant des croyances hérétiques. Cet article examine le procès et l'exécution de Hätzer afin de réfléchir à deux questions importantes pour les études du début de la Réforme : la résistance des réformateurs à engager des accusations d'hérésies contre d'autres tenants de la Réforme, et leur reconsidération de la sexualité suite au rejet du célibat sacerdotal.

$\mathrm{O}$ $\mathrm{n}$ the morning of 4 February 1529, Ludwig Hätzer was taken from his cell to the Constance city hall. He had spent the preceding night with a group of people, most prominently the city councillor Thomas Blaurer, reviewing his life and preparing for his end. The group had sung Psalms and hymns, some of which had been written by Hätzer. At the city hall, officials read the charges against Hätzer, and pronounced the punishment he was to face: death by the sword. After acknowledging the justice of the charges and punishment, he made a brief appeal to the civic authorities to forgive his crimes and to treat his father and wife with mercy. He then admonished the authorities "to love justice and mercy because their office is good and pleasing to God when properly performed" ("sy weltend gerechtigkait vnd barmhertzigkait lieb haben, dann jr ampt gut wäre vnnd Gott wolgefellig, wo es recht gebrucht wurd"). ${ }^{1} \mathrm{He}$ also

1. Manfred Krebs, ed., Quellen zur Geschichte der Täufer, vol. 4: Baden und Pfalz (Gütersloh: C. Bertelsmann Verlag, 1951), 457. All translations are mine. 
appealed especially on behalf of the imprisoned, that the authorities not leave them without consolation. He was then handed over to the executioner and bound. To the crowd assembled before the city hall, he made an appeal that they be true Christians according to the precepts of the Gospel and not just in name or vain speech. In addition, he asked them to join with him in petitioning God to watch over him and keep with him "the same covenant made with Abraham, Isaac, and Jacob through Christ Jesus, [his] Son, our Savior" ("an im halten den punt so du gemacht hast mit Abraham, Ysaac vnd Jacob durch Christum Jesum dinen sun unsern säligmacher"). ${ }^{2}$ Then began a ritualized procession along the high street to the city gate. In the upper market, the group stopped and Hätzer again addressed the assembled crowd, calling on them to observe the precepts of the Gospel not only with their mouths but also with their hearts. He led the group in public prayer and amid tears on all sides he offered forgiveness to all who had wronged or offended him in the past. The party then continued on to the place of execution outside the city gate, where a little more than a century before the notorious Bohemian heretic, Jan Hus, had been consigned to the flames. There, in the middle of a circle of the people, Hätzer was unbound and given a Psalter. From it he read aloud Psalm 25, one of the seven Penitential Psalms, and again led the group in public prayer. Stripped and again bound, in God's name he knelt before the block. The executioner then severed his head from his body and the crowd praised God. ${ }^{3}$

Hätzer's case is interesting for a number of reasons, many of them to do with the procedure followed, or not followed, in the legal process against him. But it is probably most interesting because at the time he was executed, he was himself a notorious heretic whose heterodox beliefs included Antitrinitarianism, a teaching that struck at the heart of Christian orthodoxy and for which Michael Servetus was famously burned at the stake in Calvin's Geneva twenty-four years later. Yet, there is no mention of Hätzer's heterodox beliefs in any of the court records of the proceedings. And contemporary accounts of his end

\section{Krebs, 457.}

3. This account of Hätzer's final hours was synthesized from two contemporary reports, one a chronicle from the Constance Stadt-Archiv and the other a report written by Thomas Blaurer and published in 1529. The relevant parts of both sources are available in Krebs, ed., 457-58, 465-67. See also the reconstruction of events by J. F. Gerhard Goeters, Ludwig Hätzer (ca. 1500 bis 1529) Spiritualist und Antitrinitarier: Eine Randfigur aus der frühen Täuferbewegung (Gütersloh: C. Bertelsmann Verlag, 1957), 158. 
disagree on their significance for the case against him. A chronicle preserved in the city archives identifies his crimes as adultery and possibly bigamy, but it insists as well that he was a notorious Anabaptist and that "he had written much about the Trinity and other articles of the Christian faith that had contradicted Scripture" ("vil geschriben vond der trifeltigkait vnd anderen artikeln des christenlich glaubens, aber zu wider der hailigen geschrift”). ${ }^{4}$ By way of contrast, a report written by Blaurer to Wilhelm von Zell of Mindelheim insisted that Hätzer was punished for his moral failings, not because of his Anabaptism or any of his teachings. ${ }^{5}$ Clearly, not all is as it seems here. And we are left wondering why the authorities in Constance decided to prosecute Hätzer for his moral failings rather than his heretical beliefs, especially when, as we will see, this forced them to make some questionable legal decisions. At the time of the proceedings against Hätzer, the clergy and authorities in Constance were clearly in the reforming camp. Consequently, clearing up the mysteries surrounding his case gives us the opportunity to look into two areas of interest in Reformation studies. The first of these is the rather ambiguous relationship Protestant reformers had, either as defenders of orthodoxy or as disseminators of heterodoxy, depending on one's perspective, to accusations of heresy in the early years of the Reformation. No less complex is a second issue suggested by this case, the reformers' re-evaluation and revaluation of human sexuality as they worked through the implications of their rejection of clerical celibacy and monasticism.

In the most recent and comprehensive biography of Hätzer, J. F. Gerhard Goeters has reconstructed the legal process against him and highlighted its irregularities. First and most obvious, the punishment inflicted on Hätzer was unusual in Constance at this time for the crimes alleged. Most other cases involving adultery and moral offences were punished with warnings and fines or incarceration for a time. Furthermore, the procedures involved in investigating and prosecuting this crime were unusual to say the least. It appears that throughout the case, the initiative came not from the authorities in Constance but from those in Augsburg. In the middle of November 1528, the Augsburg authorities wrote to their counterparts in Constance requesting that they arrest Hätzer. On November 20, the Constance authorities responded that he was not

\footnotetext{
4. Krebs, 457.

5. Krebs, 462.
} 
resident in the city, but that they would take measures to arrest him if he were found to be living there secretly. Eight days later, the Constance authorities again wrote to Augsburg to report that they had apprehended Hätzer and to ask for further instructions. On the basis of documents that survive, and there are precious few of them, we know only that he was suspected of "depraved vices." $^{\prime}$ It appears that he was then interrogated, and on the basis of information gathered the Constance authorities sent letters in early December to the city councils in Worms, Strasbourg, Basel, and Zurich asking for information about Hätzer's activities when he was resident in those cities. The letters to Worms and Strasbourg provide few details about what he was suspected of, indicating only that he may have fomented unrest and had been acting in an unseemly fashion. Those to Basel and Zurich are more detailed and indicate that he was believed to have caused marital dissension and been involved in serious moral breaches, and in the case of Basel there were suggestions that he may have taken several spouses. ${ }^{7}$

It seems that by December the case against Hätzer was running into problems: a number of the charges against him appear not to have been sticking, and proceedings were getting drawn out and messy. In the second half of the month, the authorities in Augsburg sent the city doctor, Gereon Sailer, to Constance to represent their interests there. Sailer brought a detailed set of questions to present to the defendant as well as two manuscripts allegedly written by Hätzer. Goeters speculates that these were "A Booklet on Christ" and "A Booklet on Schoolteachers," ${ }^{8}$ which Hätzer may have been trying to get printed in Augsburg sometime before he was apprehended in Constance. All indications are that Sailer took the lead in the case against Hätzer at this time. For example, at the end of December he was in Memmingen, soliciting the opinion of Ambrosius Blaurer, one of the leading reformers from Constance and brother of Councillor Blaurer, about some of Hätzer's beliefs. All of the evidence suggests, then, that Hätzer's crimes were committed in Augsburg rather than Constance. According to Goeters's reconstruction, in late 1527 or early 1528 Hätzer had had an illicit relationship with Anna Regel, the wife of Jörg Regel, a prominent citizen of Augsburg with whom Hätzer had earlier

6. Krebs, 456.

7. Goeters, 147-49; Krebs, 453-54.

8. Goeters, 150. 
been connected. It appears that in anticipation of her husband's demiseapparently the husband was noticeably older than his wife-Hätzer and Anna had established some sort of betrothal for which he received a ring and several loans. At the time, however, he was already married to the Regels' maid, Appolonia. Furthermore, he had devised some sort of theological justification for these unorthodox relationships. ${ }^{9}$

Goeters admits that there is sufficient evidence to suspect that Hätzer really was involved in some sort of affair with Anna Regel, but he maintains, nonetheless, that this was not the chief reason for the proceedings against Hätzer. Rather, the primary concern was Hätzer's heterodox opinions; his moral failings only provided the pretense for legal action against him. This certainly was the opinion expressed by a number of his contemporaries beyond the chronicler noted above. For example, according to the Augsburg reformer Urbanus Rhegius, it was particularly Hätzer's denial of the divinity of Christ that lay at the root of his problems. ${ }^{10}$ Strikingly, though, the court documents from Constance are consistent, and Goeters says intentional, in avoiding any reference to Hätzer's heterodoxy. Goeters is convinced that the moves against him were part of a broader crackdown on Anabaptists in the south German cities at this time. ${ }^{11}$

There is little doubt that toward the end of his life Hätzer was voicing opinions that were, by almost any measure, heterodox. In his final two, unpublished works-those introduced by Sailer into the legal proceedings against him - he made his most radical statements. While they are no longer extant, we are told by several contemporary witnesses that "A Booklet on Christ," especially, smacked of Arianism or even denied outright the divinity of Jesus. ${ }^{12}$ As well, by this point Hätzer was widely believed to be an Anabaptist, and Anabaptism had already been designated a crime worthy of the death penalty by Zurich authorities in 1526 and in imperial law in January 1528. Under these circumstances, the Constance authorities should have had no qualms about punishing him for his religious beliefs or practices.

9. Goeters, 149-55; Krebs, 454-56, 459.

10. Goeters, 151-53, 156; Krebs, 456.

11. Goeters, $152-53,157$.

12. Sebastian Franck, Chronica, Zeytbuch und geschichtbibel (1531), 415b-416; E. Egli and R. Schoch, eds., Johannes Kesslers Sabbata (St. Gallen, 1902), 306. 
Why, then, did they prosecute Hätzer for moral lapses rather than heresy? On this matter, the recent insights of Tom Scott may be valuable. Scott has noted that heresy seems in many ways to be a fundamentally medieval concept-certainly much more medieval than early modern, even. During the Reformation, there was a tendency to describe opponents more as schismatics than as heretics. Several conclusions derived from these observations seem relevant to the Hätzer case. First, Scott concludes that magisterial reformers were reticent to label other magisterial reformers heretics, no matter how much they disagreed with each other, despite the fact that their disagreements sometimes occurred over theological matters, as with the Eucharistic debates, which traditionally would have justified accusations of heresy. Their reticence, Scott continues, likely stemmed from the awareness that they themselves were open to such charges from their Catholic opponents, and the realization that divisions within their ranks could be seen as evidence that they were, in fact, sectarians. Furthermore, disagreement between the reformers called into question their claims that the plain words of Scripture contained the truth from which they could challenge the church's authority. Second, when dealing with the radicals, especially the Anabaptists, there was a marked tendency to rely on charges of blasphemy rather than heresy, although the punishments suggested often did not differ much from those traditionally applied to heretics. While, ostensibly, theological criteria were often applied when judging the Anabaptists, the concern was clearly with the seditious nature of their teachings-heresy was, in a sense, being secularized or at least politicized. However, theological criteria could still provide the basis for legal action, as in the case of Servetus, whose execution at Geneva was chiefly for denying the doctrine of the Trinity. ${ }^{13}$

Despite Scott's observations, it still seems logical that the authorities in Constance would have charged Hätzer with heresy, or at least with blasphemy. I suspect that the refusal of the authorities to follow that route likely has something to do with the path Hätzer travelled in arriving at his own unorthodox opinions and how it relates to the Reformation history of Constance. Hätzer had important connections to the reformers of Constance and, like them, he identified with Zurich rather than Wittenberg as the home of the Reformation. Bruce Gordon has described Constance as the most Swiss of all the south

13. Tom Scott, "The Problem of Heresy in the German Reformation," in The Early Reformation in Germany: Between Secular Impact and Radical Vision (Farnham: Ashgate, 2013), 185-202, especially $188-96$. 
German cities in the age of the Reformation. From its beginnings in the city, the Reformation was led by a group of humanist-minded reformers with close ties to Zwingli. New church ordinances adopted in 1526 were modelled on those in Basel; and in 1528, when the Mass was abolished in the city, Constance entered into the Christian Federation with Zurich and Bern. ${ }^{14}$ Similarly, initially at least, Hätzer's credentials as a member of the Swiss Reformation were impeccable. He likely first became involved in reforming activities as a chaplain in Wädenswil, a village a short distance from Zurich. He may have attended the first Zurich disputation (29 January 1523), which established the scriptures as the standard for religious change in the city. Likely during the summer or fall of 1523, he moved from Wädenswil to Zurich, and in October certainly attended the second disputation-on religious images and the Mass. ${ }^{15}$ On 24 September 1523, he published his own contribution to the debate about the legitimacy of religious images: Ein Urteil Gottes unsers Ehegemahls, wie man sich mit allen Götzen und Bildnissen halten soll aus der Hl. Schrift gezogen durch LH. This he followed in December with an account of the proceedings of the second disputation: Acta oder Geschichte, wie es auf dem Gespräch der 26., 27. und 28. Tagen Weinmonats in der christlichen Stadt Zürich vor einem ehrsamen gesessen grossen und kleinen Rat, auch in Beisein von mehr als 500 Priestern and viel anderer bieder Leute, ergangen ist. Betreffend die Götzen und die Messe.

However, after his initial foray into Reformation pamphleteering, Hätzer began to part ways with the Zurich Reformers. He later claimed that he was not an Anabaptist, but it seems that at this time he was drawn to the Zurich radicals, who publicly acknowledged their break from Zwingli with the first adult baptisms of the Reformation period in Zurich in January 1525. ${ }^{16}$ That same month, Hätzer was expelled from the city for his open support of them.

From Zurich he went to Constance. After a brief stay there he moved on to Augsburg, where he already had important contacts. In late 1523, he had established a working relationship with the Augsburg printer Silvan Otmar, and in the first half of 1524 Otmar published Hätzer's translations into German of two Latin works: an eleventh-century document by a former rabbi encouraging Jewish conversion to Christianity, Ein Beweis, dass der wahre Messias gekommen

14. Bruce Gordon, The Swiss Reformation (Manchester: Manchester University Press, 2002), 291-92.

15. Goeters, 9-17.

16. Goeters, 51-54. 
sei, aufden die Juden noch ohne Ursach in der Zukunftt warten, geschrieben durch Rabbi Samuel, and a commentary by Johannes Bugenhagen on Paul's epistles from Ephesians to Hebrews, Eine kurze wohlgegründete Auslegung der zehn nachgehenden Episteln S. Pauli, erstlich in Latein durch Johannes Bugenhagen aus Pommern, Bischof zu Wittenberg, geschrieben und von LH verdeutscht. In June of that year he had moved to Augsburg to oversee the printing of the latter work. At that point, he was still on good terms with Zwingli, who had written a letter of introduction for him to Johannes Frosch, an important leader of the Evangelical movement in Augsburg. This introduction appears to have gained him access to powerful individuals in Augsburg, including the reformer Urbanus Rhegius and the wealthy merchant Jörg Regel. During the summer of 1524, Hätzer established close relations with Regel, and one assumes his wife as well. However, in September, Regel and his wife were seized by the duke of Bavaria after an attack on Regel's fortress, Lichtenberg am Lech, and forced to pay a fine and swear to remain by the old faith. Likely in October 1524, Hätzer left Augsburg and returned to Zurich. ${ }^{17}$

When he returned to Augsburg in early 1525, Hätzer was unable to pick up where he had left off. Regel now avoided him and he was regarded with suspicion by the city's reformers. In September he left the city rather than face Rhegius in a disputation. However, at least for a time, he was able to reestablish connections to Silvan Otmar, who published in the summer of 1525 an original work by Hätzer criticizing the loose living among some of the socalled Evangelicals: Von den evangelischen Zechen und von der Christen Rede aus Hl Schrift.

Scholars have seen in Hätzer's preface to the Buggenhagen translation either a thinly-veiled criticism of the course of the Zurich Reformation or a general attack on all magisterial reformers for their failure to apply God's Word with all strictness and decisiveness. ${ }^{18}$ With its denunciation of socalled "Evangelical activities," Von den evangelischen Zechen casts an equally critical eye on the Reformation. However, Joel Van Amberg's recent study of the Eucharistic conflicts in Augsburg highlights the extent to which these criticisms were aimed at the Reformation there and its ties to Wittenberg as

17. Joel Van Amberg, A Real Presence: Religious and Social Dynamics of the Eucharistic Conflicts in Early Modern Augsburg 1520-1530 (Leiden: Brill, 2012), 160-62.

18. Goeters, 40-42; George Hunston Williams, The Radical Reformation, 3rd ed. (Kirksville, MO: Sixteenth Century Journal Publishers, 1992), 189. 
well. Van Amberg insists that Hätzer should be viewed at this time not as an Anabaptist but as an advocate of the symbolic understanding of the Eucharist in the debates playing out in Augsburg between the supporters of Zurich and the south German cities on the one hand and the adherents of the Wittenberg Reformation on the other. It should come as no surprise, then, that Hätzer wrote to Zwingli in September 1525 to apologize for his earlier actions and to promise greater prudence in the future. In the same letter, he also appealed to Zwingli to write against Rhegius's interpretation of the Eucharist, thereby highlighting his own role as an advocate of the symbolic interpretation of the words of institution in the city. ${ }^{19}$

Nor should we be surprised that he was able to re-establish cordial relations with the Swiss Reformers. After leaving Augsburg, he again visited Constance, where he apparently engaged in theological discussions with Ambrosius Blaurer. Blaurer's later comments to Zwingli suggest that there were tensions between the two men. Nonetheless, Hätzer was able to leave the city and travel to Basel, where he ultimately worked closely with the reformer Johannes Oecolampadius. While in the city, he produced translations of four works by Oecolampadius: two contributions to the Eucharistic debates, Vom Nachtmal. Beweisung aus evangelischen Schriften, wer die seien, die des Herrn Nachtmahlswort unrecht verstehen und auslegen and Vom Sakrament der Danksagung. Von den wahren natürlichen Verständnis der Worte Christi: Das ist mein Leib, nach der alten Lehrer Erklärung; and two commentaries on the prophets, Der Prophet Maleachi mit Auslegung Johannis Oecolampadii, durch ihn im Latein geschrieben, mit Fleiss verdeutscht durch L.H. and Das 36. und 37. Kapitel Jesaja des Propheten, ausgelegt durch Johannes Oekolampad. This activity provided him with the opportunity to work his way back into Zwingli's good graces. In the winter of 1525-26, he made several trips to Zurich, largely to oversee the publication of some of his translations but also as Oecolampadius's representative on other matters. Present in the city for the third disputation on baptism from 6 to 8 November 1525, he supported Zwingli against the Anabaptists. ${ }^{20}$ However, Hätzer's activities there and in Basel came to an abrupt end when, if we can believe a later report from the Strasbourg clergy

19. Van Amberg, 162-65.

20. Goeters, 68-82. 
to the Constance authorities, his relationship with a maid in Basel produced unwanted consequences. $^{21}$

Awareness of where Hätzer's life was headed has led scholars to overemphasize his theological departures from the official lines of the Swiss Reformation during this time. Goeters in particular has identified this as an important transitional stage in the development of Hätzer's thought. While noting that Hätzer still holds to the authority of Scripture in his preface to Vom Sakrament der Danksagung, he suggested that at this point he calls for a more spiritually informed understanding of it. In other words, his biblicism has taken on a new Spiritualist direction. This focus on the relationship between the Spirit and Scripture then becomes a principle theme in the preface to the translation of the Malachi commentary, where it is tied to a new criticism of false erudition. Goeters sees all of this as evidence of the increasing influence on Hätzer of Luther's radical opponent Andreas Bodenstein von Karlstadt. ${ }^{22}$

There is, indeed, a shift in the tone of Hätzer's discussion of the relationship between Scripture and the Spirit in these works. His early reforming vision has been characterized as being dominated by a "massive biblicism." ${ }^{23}$ This is modified, at least to a degree, in Von den evangelischen Zechen, where he repeats the apostle Paul's exhortation that believers be filled with the Spirit. ${ }^{24}$ At times, he almost seems to be setting the authority of the Spirit over that of Scripture, as when he claims that Satan has appropriated the word and we can discern his strategy only with the wisdom of the Spirit. ${ }^{25}$ But elsewhere he seems to be suggesting a complementary relationship between the Spirit and Scripture. In Von den evangelischen Zechen he calls on readers to look to the Bible, which reveals God's will, and in his preface to the Bugenhagen translation he informs readers that we are permitted to test spirits, whether they come from God or the Devil, presumably on the basis of their conformity to Scripture. ${ }^{26}$ The likelihood that at least some of this increased concern with

21. Krebs, 455-56.

22. Goeters, 73-86.

23. Goeters, 131.

24. Hätzer, Von den Euangelischen Zechen und von der Christen Rede aus Hl. Schrift (1525), b-bii(b).

25. Hätzer, Von den Zechen, aii(b).

26. Johannes Bugenghagen, Ain kurtze Wolgegründte Auslagung über die zehen nachgeenden Episteln S. Pauli, ... (1524), ii(b). 
the Spirit comes from Karlstadt is suggested by the first appearance in Hätzer's writings of the term Gelassenheit. ${ }^{27}$ These works suggest, then, that Hätzer may have had a growing awareness of possible tensions between the voice of the Spirit and some interpretations of the written word. However, there is no clear evidence that one took priority over the other in his mind.

As Goeters observed, there is a noteworthy change in the discussion of this relationship in the preface to the Malachi commentary, but it is evident already in Vom Sakrament der Danksagung as well. In the former work he still identifies Scripture as the source of truth, ${ }^{28}$ but in both prefaces he is more explicit than previously about the close relationship between the Spirit and Scripture. The Spirit is identified as the source of the Word, and elsewhere Scripture is described as the dwelling place of the Spirit. ${ }^{29}$ Consequently, the presence of the Spirit, the best teacher of Scripture, is essential to its proper understanding. In the Malachi preface, Hätzer states explicitly that without the Spirit, the letter of Scripture is useless, and in the foreword to Vom Sakrament der Danksagung he blames errors arising in the Reformation on the failure to understand Scripture spiritually. ${ }^{30}$ Connected with this emphasis on the exegetical role of the Spirit is a new, sharp criticism of the learned ones (Schriftgelehrten), who interpret Scripture in a fleshly manner. This state of affairs was predicted by Paul and mirrors the original revelation of the word to the lowly, who, in contrast to the learned, receive the Spirit in humility. ${ }^{31}$

As Goeters has noted, all of this sounds a lot like Karlstadt. However, in Hätzer's mind it is unlikely that there was a need to distinguish between the teachings of Karlstadt and those of Oecolampadius. Hätzer himself indicates that he undertook the translation of Oecolampdius's Eucharistic works on his own initiative. ${ }^{32}$ As Amy Nelson Burnett has recently informed us, Oecolampdius saw in Karlstadt's understanding of the Eucharist a complement to that of the

27. Hätzer, Von den Zechen, aii(e).

28. Hätzer, Vom Sakrament der Danksagung (1525), aii.

29. Hätzer, Danksagung, aiii(b); Hätzer, Der Prophet Maleachi mit Auslegung Johannis Oecolampadii (1526), A(b).

30. Hätzer, Danksagung, aiv(b)-av, avi-avi(b); Hätzer, Maleachi, A(b)-Aii.

31. Hätzer, Danksagung, aiiii(b)-av, avi(b)-avi(c); Hätzer, Maleachi, A(b)-Aii(b).

32. Hätzer, Danksagung, avi(b). 
Swiss Reformers. ${ }^{33}$ And in the text of Oecolampadius's works there appear solid complements to Hätzer's reading of Karlstadt, including a stress on the necessity of the presence of the Spirit to enliven the letter, which is potentially dead in both testaments of the Bible. ${ }^{34}$ Certainly, there is no evidence that the Swiss reformers were looking askance at any of these comments in Hätzer's prefaces at the time.

From Basel, Hätzer moved to Strasbourg. He likely arrived in the city sometime in December 1526 and stayed until late January or early February 1527. At least initially, he was well received by the leading reformers in the city, especially Wolfgang Capito, whose guest he was for some of his time there. However, Capito and the other reformers became increasingly concerned about the extent to which Hätzer was coming under the influence of the Spiritualist Anabaptist Hans Denck, whom the reformers described as a "sly hypocrite" and a "deceiver of people." Concerns about Denck's activities soon led to his expulsion from the city, followed soon after by Hätzer's voluntary departure. They reunited shortly thereafter in Worms, where they appear to have worked closely on several projects, including Alle Propheten, nach der hebräischen Sprache verdeutscht, the first translation from Hebrew into German of the Old Testament prophetic books. The striking thing about Alle Proheten was that it was much more a scholarly than a "radical" translation. James Beck has characterized it as the work of Christian Hebraists concerned first and foremost with the integrity and accuracy of their translation. Notable is the absence of a Christological reading of the prophets, and there is some speculation that this work encouraged Hätzer's later Antitrinitarianism. ${ }^{35}$ However, the initial reaction to Alle Propheten was mixed: the city of Nuremberg banned its sale in 1527, but the same year in a private letter Luther criticized only the confusing nature of the language it employed. ${ }^{36}$

33. Amy Nelson Burnett, Karlstadt and the Origins of the Eucharistic Controversy: A Study in the Circulation of Ideas (Oxford: Oxford University Press, 2011), 92, 96-97, 99.

34. Hätzer, Danksagung, Kv(f); Hätzer, Maleachi, Fii.

35. James Beck, "The Anabaptists and the Jews: The Case of Hätzer, Denck and the Worms Prophets," Mennonite Quarterly Review 75 (2001): 422-25; Martin Rothkegel, “Täufer, Spiritualist, AntitrinitarierNikodemit. Jakob Kautz als Schulmeister in Mähren," Mennonitische Geschichtsblätter 57 (2000): 51-88. 36. Beck, 407-08. 
But three years later, Luther complained that he could see the influence of the Jews in the translation. ${ }^{37}$ In between these comments, Hätzer's name had become synonymous with heresy. However, even the process by which this occurred is available to us only in its broadest outlines and seems as much a result of rumour as accurate reporting. On 7 June 1527, the Friday before Pentecost, while Denck and Hätzer were likely still in the city, Jacob Kautz posted 7 Articles on the door of the Dominican church in Worms. These were intended as the basis for a disputation with the local Lutheran clergy set for one week later. When the clergy declined this invitation, Kautz, another local reformer known only as Hilarius, and two "unnamed brethren" explained the theses in a public sermon. There is no clear evidence of Hätzer's involvement in this activity, although one copy of the articles preserved by a chronicler from Worms contains not only Kautz's name, but also those of Denck, Hätzer, and Melchior Rink. ${ }^{38}$ Thereafter, Hätzer's trail becomes less clear. He may have returned to Strasbourg and then Augsburg, where he may have attended the Martyrs Synod in August. After leaving Augsburg, he may have visited Nuremberg, Donauworth, and Regensburg. In the last of these he is alleged to have baptized three men and a woman. ${ }^{39}$ However, this charge seems at odds with the increasingly Spiritualist orientation of his ongoing publishing activity, which included translations of some of the wisdom literature of the Old Testament Apocrypha, Baruch der Prophet, die Historie Susannas, die Historie vom Bel zu Babel, alles neulich aus der Bibel verdeutscht, and an edition of the Theologia Deutsch, Theologia Deutsch, neulich mit grossen Fleiss korrigiert end gebessert. Nonetheless, in all of this he was increasingly being identified with departures from both orthodoxy and orthopraxis.

Of relevance to the present discussion, though, is the gradual nature of this process. He first became openly identified with Denck and with heretical or blasphemous opinions toward the end of 1526. Before that, he had a close working relationship with Reformers in Zurich, Basel, and at least to some degree Constance. True, he had wandered from the straight and narrow path, most notably in early 1525 , but he had repented the error of his ways and

37. Beck, 408.

38. Werner Packull, Mysticism and the Early South German-Austrian Anabaptist Movement 1525-1531 (Kitchener, ON: Herald Press, 1977), 57.

39. Goeters, 121. 
returned to the fold. Both before and after that episode, he had performed valuable services to the Swiss and south German Reformation, especially by writing pamphlets that endorsed the reforming agenda, translating a number of important works by the reformers, and defending the symbolic understanding of the Lord's Supper in Augsburg. His translations, especially, left his name linked directly to those of important members of the reforming community. Consequently, to charge him with heresy could conceivably call into question the orthodoxy of their enterprise as well.

That left the option of charging Hätzer with moral lapses, a charge to which he had so conveniently left himself open. And yet, prosecution on that basis appears not to have been straightforward. According to imperial law, adultery and bigamy could be punished by death. Nonetheless, Goeters claims that this was not the practice in Constance, and when the case against Hätzer seemed to be running into trouble, Sailer introduced Hätzer's compromising writings into the case. These difficulties open new perspectives on the relationship between the Reformation and the maintenance of public order. Some time ago, Lyndal Roper argued that the reformers' rejection of celibacy as a state pleasing to God and their repudiation of clerical celibacy encouraged them to rethink the relationship between sexuality and the sacred. This led ultimately to Protestant familialism, which made sexuality spiritually neutral and channelled it into the institution of marriage, thereby turning it from a disruptive force into a pillar of social stability. However, at first this was a "troubled and incomplete" process, and focusing on its end product risks obscuring the extent to which different views on marriage and sexuality appeared during the early Reformation. ${ }^{40}$ These are most obvious in high profile cases like the polygamy of Anabaptist Münster, but, Roper argues, the magisterial reformers' reliance on biblicism as the sole judge of morals and the example of the marital practices of the Old Testament patriarchs could also be problematic. The best known and most obvious consequence of this was the reformers' complicity in the bigamy of Phillip of Hesse a full decade after Hätzer's case. ${ }^{41}$ Could Hätzer's case have suffered from similar ambiguity in early Protestant definitions of legitimate marriage?

40. Lyndal Roper, "Sexual Utopianism in the German Reformation," Journal of Ecclesiastical History 42 (1991): 394-418, especially 394-96, 412.

41. Roper, 413-14. 
The paucity of clear records surviving from the trial makes a definitive answer to that question impossible. However, there is no indication at all in the surviving statements regarding Hätzer's case that anyone had any doubt that his actions were wrong. Furthermore, recent research by David Whitford has called into question the extent to which Reformation biblicism changed in any significant way peoples' thinking about sexual morality and the nature or structure of marriage. Whitford has investigated the vacillations in Luther's statements about bigamy and discovered that they were driven not so much by the dictates of the biblical example or even strictly pastoral concerns as by his relationship to the person in question: Luther was permissive on such matters when referring to those he cared about and severe or harsh on those with whom he disagreed or whom he regarded as his foes. ${ }^{42}$ It would seem, then, that biblical examples of polygamy could serve as ex post facto justifications for close or important allies rather than general dictates about the nature of marriage. If we were to extrapolate from Whitford's conclusions, it would seem that as a suspected Anabaptist and Antitrinitarian, as well as a general thorn in the sides of the reformers, Hätzer hardly merited a biblical justification for his moral lapses.

The introduction of Hätzer's heterodox writings into the trial in the middle of December suggests that another dynamic was at work here. It seems more likely that Sailer and the Augsburg authorities were either having trouble making their case that Hätzer was guilty as charged or that his crimes warranted the death penalty. In either case, his heretical beliefs would have had a relevance that may not be immediately apparent. Throughout the history of Christianity, up and into the time of the Reformation, sexual impropriety had close connections to heresy. According to Norman Cohn, these connections go back to charges levelled against Christians in the Roman Empire as early as the second century. Then, accusations of cannibalism and incestuous orgies may have been derived from descriptions of the agape meal. ${ }^{43}$ With the legalization of Christianity in the empire, similar charges were turned against heretical

42. David Whitford, “'It Is Not Forbidden That a Man Have More Than One Wife': Luther's Pastoral Advice on Bigamy and Marriage," in Mixed Matches: Transgressive Unions in Germany from the Reformation to the Enlightenment, ed. David Luebke and Mary Lindemann (New York: Berghahn Books, 2014), 14-30.

43. Norman Cohn, Europe's Inner Demons: The Demonization of Christians in Medieval Christendom, revised ed. (Chicago: University of Chicago Press, 1993), 1-4, 10-11. 
groups, primarily in the eastern parts of the empire. For example, in the early church, Manicheans were suspected of practising erotic debauches, often involving incest, infanticide, and cannibalism. With time, such charges took on greater clarity and more lurid contours and were applied to more heretical groups. Until the eleventh century, the western parts of Europe had been spared much of the dissent so evident in the east and the accusations that went with it. But these matters moved west at that time and grew quickly in currency and stature after that. ${ }^{44}$

A crucial stage in the expansion of charges against heretics in the west came with Gregory IX's papal bull Vox in Rama (1233), which, according to Cohn, turned tales of incestuous orgies among heretical groups into "established truths." Thereafter, accusations of sexual debauchery became stock charges against a variety of heretics in the west-Robert Lerner describes the equating of heresy with fornication as a topos of the thirteenth century and a common-place assumption of the fourteenth..$^{45}$ This had a profound effect on the understanding of the relationship between sexual excess and heresy at both juridical and popular levels. By the early fourteenth century, in both inquisitorial procedure and its theological justifications, aberrant sexual behaviour was treated automatically as a sign of heresy, and heretical deeds were seen as the means to discovering heretical teachings. ${ }^{46}$ This thinking could also filter down to a more popular level-in the fifteenth century in southern Germany, the term Ketzerei could mean both heresy and sodomy. ${ }^{47}$

Evidence suggests that this thinking persisted into the age of the Reformation, explicitly among Catholics and at least implicitly among Protestants. Responses of Catholic polemicists to Luther's marriage and to clerical marriage more generally identified this practice as not only depraved but heretical as well. For example, Thomas More's Dialogue Concerning Heretics (1531) referred more than sixty times to Luther's incestuous marriage to his spiritual sister, the former nun Katharina von Bora. For Catholic polemicists,

44. Cohn, 35-41.

45. Cohn, 41-78; Robert Lerner, The Heresy of the Free Spirit in the Later Middle Ages, reprint ed. (Notre Dame, IN: University of Notre Dame Press, 1972), 20-34.

46. Irene Bueno, Defining Heresy: Inquisition, Theology, and Papal Policy in the Time of Jacques Fournier, trans. Isabella Bolognese, Tony Brophy, and Sarah Rolfe Prodan (Leiden: Brill, 2015), 127, 335-36.

47. Thomas Fudge, The Trial of Jan Hus: Medieval Heresy and Criminal Procedure (Oxford: Oxford University Press, 2013), 64-65. 
clerical marriage amounted to committing heresy with one's body. While Luther and other reformers defended clerical marriage as being in accordance with the divine plan for humans to go forth and multiply, and an exercise of the freedom granted by the gospel, they continued thereby to maintain a connection between sexual morality and theology. ${ }^{48}$ As a result, for an outsider like Hätzer, who stepped beyond the bounds of a legitimate, monogamous union, there was no defence, whatever the Bible said about the marriage patterns of the patriarchs. In this case, at least, the "troubled and incomplete" process by which the reformers rethought the relationship between sexuality and the sacred appears not to have played a role.

Prosecuting Hätzer for adultery and bigamy, then, involved not so much adopting a completely different charge from heresy as it did getting to that charge by a different path. If attacking his beliefs directly carried a risk of compromising the position of the reformers in Constance and elsewhere, criticizing his morals could still highlight the danger he posed to society as a heretic. This, I believe, explains the introduction of his "heretical" unpublished manuscripts to the proceedings when the prosecution's case ran into trouble. If Hätzer's moral failings were an indication of his heretical beliefs, then his heretical beliefs were a confirmation of his moral depravity. The fact that the official reason for his execution was adultery, but everyone seemed to know that the real reason was heresy, should come as no surprise. For his contemporaries, the distinction between these two things was not nearly as clear as it is for us.

Hätzer's trial was, then, in important ways still very much a medieval event. This fact helps to explain another interesting aspect of this case: the ritualized nature, or perhaps the ritualized reporting, of his final journey from the city hall to the site of execution. Recent studies of late medieval and early modern punishment have highlighted the importance of ritual, especially in late medieval executions. Beginning in the fourteenth century and becoming firmly established during the course of the fifteenth on the Continent, public executions became highly ritualized affairs with strongly religious overtones. In contrast with earlier rituals of punishment, which often aimed at reinforcing the exclusion of the condemned from the community, during this time there was an increasing emphasis on the possibility of a good death for a repentant 
criminal with the possibility of posthumous grace and, with it, redemption and reintegration into the community. Beginning in the early fourteenth century, confession was offered to the condemned, and during the later part of that century and into the fifteenth in some places it became compulsory. In this way, not only the individual but also the community as a whole found redemption through the individual case of atonement. ${ }^{49}$

All of these elements appear in the surviving accounts of Hätzer's death. Clearly, his journey through the city was a ritualized and highly stylized affair. At each stage in the journey, he was reconciled with different elements of the city's population. The vigil during the night before the execution saw him reconciling with Blaurer and others who had grown close to him. At the city hall the next morning, he acknowledged the justice of what was to happen to him and made peace with the city authorities, whose office he recognized as legitimate. At the city hall, in the upper market, and at the site of execution, he made peace with the people as a whole. In each of these cases, reconciliation accompanied an affirmation of religious orthodoxy, through singing songs and Psalms during the vigil, repeated prayers at various stages during the journey, and reading the penitential Psalm at the end. If we can believe the reports, with his death Hätzer worked to restore the Christian unity that had been threatened by his actions and teachings. This seems ironic for a man who saw in Jesus a sage and teacher and not an atoning sacrificial lamb.

49. See Esther Cohen, The Crossroads of Justice: Law and Culture in Late Medieval France (Leiden: Brill, 1993), 198-200; Paul Friedland, Seeing Justice Done: The Age of Spectacular Capital Punishment in France (Oxford: Oxford University Press, 2012), 13, 89-115. It appears that similar changes occurred somewhat later in England; see Katherine Royer, The English Execution Narrative, 1200-1700 (London and New York: Routledge, 2014), 7. 